Skaidra Trilupaityte

\title{
SPĄSTAI ŽMOGAUS PASAULIUI
}

Shoshana Zuboff.

The Age of Surveillance Capitalism: The Fight for a Human Future at the New Frontier of Power. New York: PublicAffairs, 2019, 704 p.

Sekimo kapitalizmas, pasak Harvardo universiteto filosofés ir socialinės psichologijos profesorès Shoshana’os Zuboff, yra nauja ekonominè tvarka, kurioje veikiančios didžiosios informacinių technologijų (IT) kompanijos naudoja skaitmeninius įrankius tam, kad įsiskverbdamos ị žmogaus išorini bei vidini pasaulius, gautų maksimalų pelną. Ši ilgai laukta knyga (Lietuviškai versčiau „Sekimo kapitalizmo amžius: Kova užžmogaus ateitị naujosios galios fronte“; būtent žodis frontas šiuo atveju, ko gero, tinkamiausias kovinei knygos retorikai apibūdinti) negailestingai dekonstruoja gana specifinius ir etiniu požiūriu abejotinus skaitmeninès ekonomikos procesus. Dèl aktualios staigiai išaugusių JAV didžiųjų imonių (Big Tech) kritikos Zuboff kartais netgi vadinama šiandienos Karlu Marxu, jos magnum opus buvo lygintas ir su knygoje cituojamo Thomaso Piketty kapitalizmo XXI amžiuje ekonominiu tyrimu. Nors pati autore, rodos, mieliau remiasi Hannah'os Arendt totalitarizmo reiškinio analize, Theodoro Adorno, Jeano Paulio Sartre’o, Karlo Polanyi ižzalgomis ar referencijomis ị Maxą Weberị, Emile’ł Durkheimą ir apskritai socialinių mokslų, visų pirma socialinès psichologijos, klasikų idèjas.

Aptariant teorinių prielaidų aspektus, sekimo kapitalizmo koncepcija kartais sulaukia priekaištų dèl istorinių ar pan. „neapsižiürèjimų“1. Tačiau minimo veikalo

1 Nors šioje recenzijoje nesiekiama išsamiau apžvelgti gausių autorès teorinių prielaidų, galima paminèti, jog knyga, pvz., kritikuota dèl to, jog sekimo ir priežiūros analizėje visiškai ignoruota Michelio Foucault figūra. 
stiprybes ir silpnybes, manau, produktyviau analizuoti ne tiek kreipiant dèmesi $i$ $\mathrm{XX}$ a. vakarietiškos filosofijos istoriją, bet labiau turint minty tai, jog XX a. pabaigoje (maždaug nuo 8-ojo deš.) išsivysčiusias visuomenes tyrusių autorių tekstuose rimtesnè kapitalizmo kritika užleido vietą „neutraliems“ informacinès visuomenès aprašymams. Nuosaikiai, netgi optimistiškai, vertinusi naujausias technologijas Zuboff anuomet taip pat natūraliai papildè tą plejadą akademinių mąstytojų, kurie gana pozityviai žvelgè ị naujosios ekonomikos galimybes. Beje, samprotaudama apie postindustrinès (arba postfordistinès) eros ateiti, mokslininkè anksčiau pasitelkè ir dabartinejje knygoje ignoruojamo Michelio Foucault priežiūros aparato koncepciją. Pastaroji visų pirma pasitarnavo rašant apie (post)industrinio kapitalizmo „vadybinio stiliaus" kontrolę, jau senokai susiliejusią su skaitmeninio administravimo pavidalais.

Zuboff dėstymas universitetiniame verslo mokyklos padalinyje greičiausiai taip pat lẻmé, jog ankstesnèse knygose ir tekstuose, ypač tyrinëjant informacinių technologijų poveikị darbo vietoms, galima buvo justi ir viltis, ir kai kuriuos nusivylimus skaitmeninio kapitalizmo pažadais ${ }^{2}$. Pasak pačios autorès, sekimo kapitalizmu ilgainiui ịvardytą reiškini ji pradẻjo analizuoti 2006 m., darydama interviu su kompanijų ikūrejjais, entrepreneriais, inžinieriais JAV ir JK. O šios tyrèjos akademinès minties genealogiją akyliau analizavęs Evgeny Morozovas, akcentavęs ankstesniuose Zuboff veikaluose išryškintus du prieštaringus postindustrinio kapitalizmo administravimo imperatyvus - informavimą ir automatizavimą - atskleidè, kokiu būdu, tęsdama savo keleto dešimtmečių veiklą, Harvardo mokslininkẻ sukūrè ir sekimo (kiti gal mieliau sakytų priežiūros) kapitalizmo teoriją. Pastaroji, pasak Morozovo, kol kas yra „tamsiausia ir distopiškiausia jos intelektinio arsenalo priemone ${ }^{\text {“3 }}$.

Aptariamojoje knygoje autore aiškiai pademonstravo, jog pasaulio skaitmeninimas pakankamai ilgą laiką vyksta ne tik kuriant vartotojams „draugiškesnius“ produktus ir paslaugas, bet ir kai kurioms technologijų kompanijoms iggaunant anksčiau nęsivaizduotą monopolinę galią verslo pasaulyje, nẻ nekalbant apie politinę ir socialinę ịtaką. Apžvelgusi kai kurių socialinių mokslų ir taikomosios matematikos bei duomenų analitikos istorinę raidą ir pastarujų dešimtmečių proverži paskatinusius politinius procesus, teisminius precedentus, surinkusi daugybę interviu, žiniasklaidos medžiagos ir t. t., Zuboff ịvardijo konkrečius principus, kuriais besiremdamos tokios didžiosios kompanijos kaip Google, Amazon ar Facebook palaipsniui perkonstruoja mūsų pasaulį. Šiuos procesus iggalino itin galingi kompiuteriai, nauji vadinamieji mašininio mokymosi įrankiai ir internetinių platformų verslo būdai.

2 Bene dažniausiai minimas šios autorès ankstesnis $1988 \mathrm{~m}$. veikalas - In The Age Of The Smart Machine: The Future Of Work And Power. New York: Basic Books.

3 Evgeny Morozov, "Capitalism's New Clothes: Shoshana Zuboff's new book on "surveillance capitalism" emphasizes the former at the expense of the latter", February 4, 2019, The Baffler. Prieiga per internetą: https://thebaffler.com/latest/capitalisms-new-clothes-morozov 
Nors daugeliui interneto vartotojų vis dar atrodo, jog technologijų verslo „begemotais" virtusios progresyvių jaunų programuotojų kadaise įkurtos kompanijos viso labo sprendžia kasdieninès komunikacijos, internetinès prekybos ir pan. problemas, Zuboff parodo, jog yra ne visai taip. Šiame kontekste verta prisiminti ir ilgą laiką postindustrinių šalių medijas užvaldžiusį techno optimizmą, visų pirma JAV, bet ne ką mažiau ir kitur. Juk ne vieną dešimtmetị politiniai lyderiai buvo užburti skambių IT kompanijų šūkių apie sparčiai diegiamas inovacijas bei mėgavosi vizionieriškomis skaitmeninio pasaulio guru TED stiliaus kalbomis. Šauniųjų sekimo kapitalistų pažadai yra jaunatviški ir viliojantys, o jų balsai saldūs. Savo ruožtu, šiandien žymiausių milijonieriais gana greitai tapusių startuolių ịkūrèjų lobistinẻ galia politinio veikimo lauke yra triuškinanti ir praktiškai (vis dar) neatremiama.

Zuboff itin daug dèmesio, ypač knygos pabaigoje, neatsitiktinai skiria technologijų staigios plètros "neišvengiamumo“ retorikai ir parodo, kaip kalbos apie nesustabdomą pažangą užliūliavo kritini mūsų mąstymą. Net ir šviesiausi protai šiandien suvokia, jog apie įvairias kasdien atsirandančių arba „patobulinamų“ skaitmeninių produktų šalutines pasekmes ir padarinius geriau nẻ negalvoti, mat jų variacijų neįmanoma numatyti. Tokiame kontekste kritiškumą keičia abuojumas ar netgi ciniški pa(si)teisinimai. Neretai girdime sakant - „aš neturiu ko slèpti, todèl man visiškai nesvarbu, kokius duomenis JIE apie mane renka“. Dažnas taip pat mano, jog vienintelè asmeninè informacija, kurią JIE apie mus gali būti sukaupę, yra būtent ta, kurią mes patys JIEMS „leidžiame turèti“. Sąmoningesni interneto vartotojai naudoja ịvairius skaitmeninių platformų jiems siūlomus „privatumo saugiklius“ arba "nustatymus“ bei ịsivaizduoja, jog tokiu būdu gali patys kontroliuoti informacijos apie save srautus. Deja, Zuboff „išpreparuoja“ asmens privatumo sampratas ir detaliai paaiškina, jog absoliuti dauguma dabartinės skaitmeninès ekonomikos procesų orientuoti ne į šiandienos pasaulio problemų sprendinius ar individualaus vartotojo komfortą, bet $\mathfrak{i}$ kitus dalykus.

\section{Skaitmeniniai plèšiniai nematomuose privatumo frontuose}

Aiškinantis, kuo pasižymi kasdieninị mūsų gyvenimą užvaldžiusi sekimo logika, visų pirma reikia akcentuoti, jog skaitmeninè ekonomika pati savaime nèra sekimo kapitalizmo sinonimas - šiuo atveju kalbama apie specifinius, kompanijoms greitą ir îspūdingą pelną atnešančius procesus, arba skaitmeninès erdvės „nulaužimą“, kurio paprastam vartotojui nę̇manoma nei atpažinti, nei juo labiau kaip nors iššifruoti. Automatizuotas didelio kiekio duomenų siurbimas programoms įsiskverbiant ị sistemas (data scraping) sukūrè gana specifinị verslo modelị. Pirmine žaliava arba preke čia tapo ne tiek vartotojo sąmoningai paliekami pèdsakai tinkle (ịrašai 
ar žymèjimai socialiniuose tinkluose, pirkinių užsakymas, individualūs veiksmai pažinčių programèlèse), bet nesąmoningi naršymo ịpročiai, bendravimo stilius, iqvairiausios buities gyvenimo akimirkos, balsas, judesiai ir visa tai, kas vis didesniu mastu šiandien naudojama ir žmonių analitikoje.

Tokie pokyčiai pradejjo ryškèti tuomet, kai papildomi arba pertekliniai skaitmeninès ekonomikos duomenys, kurie kažkada buvo traktuojami tiesiog kaip skaitmeninès atliekos (digital exhaust, data exhaust), buvo pradèti interpretuoti kaip duomenys, turintys dideli ateities potencialą ${ }^{4}$. Zuboff mini maždaug 2000-2002 metus, kai elgesio numatymo ir netgi jo formavimo praktikos naudojant naujas skaičiavimo metodikas radosi kaip Google kompanijos inovacija. Savo ruožtu, šios kompanijos pelną staigiai išauginęs verslo modelis ilgainiui migravo ị kitas kompanijas - Facebook, Microsoft, Amazon ir t. t. Šie procesai ir ženklino skaitmeninès ekonomikos lūžį arba transformaciją i tai, ką minètus procesus analizuojanti mokslininkè sieja būtent su sekimo kapitalizmu.

Pritaikant sudètingus matematinius modelius minètosios skaitmeninès atliekos leidžia patiems ịvairiausiems verslams iš anksto nuspèti tam tikrų grupių preferencijas kasdieniame gyvenime. Beje, ne tik tam tikro modelio batų ar mégiamiausių restoranų pasirinkimą. Žinoma, pirminiai mūsų duomenys svarbūs marketingo srityje, tačiau, pasak Zuboff, sąmoningai pateikiama asmeninè informacija sekimo kapitalizmui nèra pati aktualiausia. Kur kas daugiau duomenų naudojama ne tam, kad palengvintų žmonių gyvenimą gerinant paslaugas, bet tam, kad jų dèka galima būtų treniruoti algoritmus kuriant predikcijos modelius ir elgesio pavyzdžius. Turedamos galingus treniravimui skirtus algoritmus, didžiosios kompanijos sužino ir tai, kaip žmonès su tam tikromis charakteristikomis tipiškai elgsis tam tikromis aplinkybemis ne tik artimiausiu metu, bet ir ateityje. Šis knygos tekstą punktyru lydintis perspèjimas apie sekimo kapitalizmo beprecendị skverbimąsị i žmogiškojo pasaulio gyli ir plotị, siekiant nusavinti visas suverenios ateities galimybes, ir yra vienas pagrindinių Zuboff distopijos štrichų.

Big Tech kompanijos, beje, ne sykị teigè, jog predikcijos algoritmai yra naudingi mums visiems. Iš tiesų, sunku paneigti, jog daugeliu atvejų jie padeda gerinti produktus ir paslaugas. Pvz., gramatikos klaidas taisantis algoritmas tobulëja ir mokosi kartu su rašančiuoju, taigi vadinamasis dirbtinis intelektas ilgainiui pradeda teisingai numatyti žodị, kurị dar tik pradèjote spausdinti, galiausiai gana tiksliai pasiūlo teisingą frazę. Rekomendaciniai algoritmai „sužino“, koks filmas arba muzikos kūrinys (galimai) geriausiai atitinka jūsų skonị ar netgi dabartinę nuotaiką.

4 Atliekamos žaliavos arba pertekliaus metafora šiuo atveju itin taikliai paaiškina būtent tai, jog realiai kompanijos naudoja žymiai daugiau mūsų duomenų, nei jų reikia konkrečios paslaugos gerinimui ar produkto tobulinimui. 
Ivairių pavyzdžiu yra begalès. İsijungę kompiuterio ekraną, taip pat nuolat susiduriame ir su mums pritaikytomis reklamomis. Beje, žmonès dažnai neturi nieko prieš tikslines arba "personalizuotas" reklamas ir džiaugiasi geresnèmis, konkrečiai jiems pritaikytomis, paslaugomis. Tačiau svarbiau šiuo atveju suprasti, jog asmeninès predikcijos duomenys leidžia kurti ateities elgesio modelius ir ilgainiui pasiūlo būdus kaip šį elgesị pakeisti. Kitaip tariant, perteklinès elgesio informacijos srautų (behavioral surplus) galutinis tikslas yra žmogaus modifikacija. Kaip vienas didesnių nesusipratimų šiame kontekste, pasak Zuboff, yra įsivaizdavimas, jog sekimo kapitalizmas pasireiškia tik tada, kai esame prisijungę prie interneto, o komercinius santykius neva iliustruoja tik ekrane iššokančios tikslinès reklamos.

Verta atkreipti dèmesị ir ị viešosios politikos lygmenyje periodiškai išryškèjančias kalbas apie būtinybę stiprinti skaitmeninius asmens privatumo riboženklius. Minètą naujosios industrijos pelną generuojančią veiklą paprastai užtemdo patraukli ir ịtrauki retorika - skambios kalbos apie interneto demokratizavimą, pagalbą viso pasaulio žmonèms, individualaus vartotojo igalinimą ir pan. Deja, inžinerinė platformų verslo varikliu puse sukonstruota taip, kad liktų nepastebima. Zuboff žodžiais tariant, minètos retorikos tikslas - nukreipti mūsų dėmeși ir paskandinti mus visus daugybės neaiškių terminų jūroje, visiems laikams. Žiniasklaidoje girdimi kompanijų šūkiai - Facebook siekis sujungti žmoniją (connecting people), google pasiryžimas nebūti blogiu (don't be evil), to paties Facebook prieš pora metų skambejjusi „pranašystë“, jog ateitis yra privati (the future is private) turi mažai ką bendro su tuo, kas iš tiesų inžineriniame lygmenyje daroma, pvz., su Facebook ar Google fotografijomis, arba kuo minta srautus amplifikuojantys algoritmai. Viešųjų ryšių ir tam tikrų žiniasklaidos kampanijų kritinè analizè šiuo atveju yra vienas iš svarbių knygos dèmenų.

Autore konkrečiais pavyzdžiais pailiustravo, jog reikalavimas, kad Silicio slènio milžinai pradètų pagaliau patys savo noru saugoti mūsų privatumą, yra tradiciné analitiné klaida. Minètasis reikalavimas, pasak mokslininkès, skamba panašiai paradoksaliai kaip kad skambètų reikalavimas Henry Fordui pradèti gaminti žymųji modelio $\mathrm{T}$ automobili rankomis, arba liepimas žirafai susitrumpinti kaklą. Tokio iš pažiūros nuoširdaus reikalavimo absurdiškumą rodo ir faktas, jog jo igyvendinti JAV gana ilgą laiką nepavyko jokiomis politinėmis priemonėmis. Tai iliustruoja netgi vèlesni už knygą pavyzdžiai - tarkime, praejjus vos porai mẻnesių po to, kai 2019 m. balandžio pabaigoje Facebook vadovas Markas Zuckerbergas skambiai pareiškè, jog ateitis yra privati (the future is private!) JAV Kalifornijos teisme buvo svarstomas individualių vartotojų prieš kompaniją paduotas ieškinys, žmonėms beviltiškai siekiant išsiaiškinti, kokius duomenis apie juos Facebook perdave JAV Prezidento rinkimų skandale išgarsejjusiai Cambridge Analytica kompani- 
jai $^{5}$. Itin išsamiai ir ịdomiai Zuboff knygoje analizuojamos ir pasaulyje kažkada išpopuliarejusio papildytos realybès žaidimo „Pokemon Go“ prielaidos, t. y. nauji pasaulio žemèlapio kūrimo ir geolokacijų komercinimo būdai, kuriuos autorè aprašo kaip vieną pačių didžiausių Google inicijuotų (per kitas kompanijas) eksperimentų, o patị procesą metaforiškai ịvardija kaip (švelnų) gyvūnų bandos suvarymą i iš anksto numatytas vietas.

Kadangi minètasis skaitmeninès vertès perteklius, kurị mes patys to nè nenutuokdami paliekame kažkam KITAM, yra tipiška „naujoji nafta“, Zuboff nevyniodama ị vatą kalba būtent apie skaitmeninès kolonizacijos arba duomenų grobimo (angl. data robbery) procesą. Galima būtų tiesiog vardyti pastarųjų metų teisines kovas, kuriose dèl nesąmoningo žmonių aktyvumo rungiasi didieji sekimo kapitalistai. Savo ruožtu dèl komercinio algoritminio verslo slaptumo net ir labiausiai informuoto „eilinio individo“ pastangos suvokti, kaip konkrečiai cirkuliuoja skaitmeninè informacija, dažniausiai pasmerktos nesèkmei. Tarkime, knygoje minimi kai kurie informacinio pasaulio įrankiuose gerai besigaudantys asmenys, siekę išsiaiškinti, kaip socialiniai tinklai naudoja iš individų "profilių“ surenkamus duomenis; deja, net ir po eilès teisinių procedūrų sužinoti tikrą informacijos cirkuliavimo mastą buvo ne tik be galo sunku, bet dažnu atveju ir neįmanoma ${ }^{6}$.

Kai kurie Zuboff aprašyti faktai iš tiesų glumina. Tarkime, išmaniųjų namų aplinkai atstovaujantị balso asistentą, dulkių siurblį-robotą, termostatą, vaikišką žaislą ar čiužinị ịsigiję vartotojai tiesiog nežino (ir negali žinoti), kaip bus naudojami iš sumanios buitinès ịrangos gaunami duomenys, kurie yra perduodami daugybei trečiųjų šalių. Vartotojai negali žinoti ir to, jog gaminiuose, pvz., gali būti įmontuoti mikrofonai arba kameros (kurių buvimas net nèra identifikuojamas vartotojams skirtose produktų naudojimo instrukcijose) ir kurie visiškai nereikalingi tiesioginei daikto funkcijai. Jei vartotojai kokiu nors būdu apie tai sužino, viešojoje erdvejje kyla pasipiktinimas, vèliau sujudimas nurimsta, situaciją užglaistančios kompanijos pasižada bendradarbiauti su valdžios institucijomis, o žiniasklaida jau būna atradusi naujas skandalingas temas ${ }^{7}$. Tuo pat metu tie patys produktai ir jų funkcijos dažniausiai perorganizuojami arba pervadinami kitokiais vardais ir iš vartotojų perspektyvos „nenormaliai“ atrodžiusi situacija „normalizuojama“ (o duomenys ir toliau plèšiami visais įmanomais, nors ir nematomais, būdais). Ir taip iki kito skandalo.

5 Didžiosios kompanijos teisininkai tuo tarpu teisme įrodinėjo, jog jei vartotojas kažkuo pasidalino platformoje, tokia medžiaga de facto nebera privati.

6 Minètinas kad ir plačiai knygoje aprašytas Facebook operacijas siekusio išsiaiškinti belgų matematiko ir duomenų apsaugos aktyvisto Paulo Oliverio Dehaye, $2016 \mathrm{~m}$. pradejusio oficialios užklausos procesą, „kryžiaus kelių“ pavyzdys.

Zuboff savo interviu kartais mini ir (sąlygiškai naują) NEST kamerų pavyzdị: https://www.cnet.com/ home/smart-home/google-calls-nests-hidden-microphone-an-error/ 
Paprastai tariant, vis dar (beveik) nereguliuojamo grobimo, arba nematomo žmogaus duomenų ir elgesio plěšimo - manau, jog plešinių metafora šiuo atveju būtų gana taikli - situacija iš tiesų leidžia samprotauti apie mūsų pasauliu slenkantị nematomą, kartais nebent teismuose identifikuojamą, privatumo frontą. Žinoma, išsyk privalu pripažinti, jog tiek pati Zuboff knyga, tiek ir įvairių aktyvesnių visuomenès grupių bei politikų augantis sąmoningumas iliustruoja būtent kritinès refleksijos pradžią, ar bent jau skaudų pri(si)pažinimą, jog informacija apie mus skiriama ne mums, bet nesuvokiamam Didžiajam Kitam.

\section{Didysis Kitas kaip totalitarizmo tropas}

Svarbu akcentuoti, jog sekimo kapitalizmo režime nèra ne tik fizinès ar psichologinès prievartos, bet ir sąmoningo apsisprendimo. Individai nesuteikia bendrovems prieigos prie savo potyrių noriai ar (ne)noriai vykdydami kokią nors pareigą, jie to nedaro ir „pasirinktinai“. Žinia, toks i̇spūdis gali kilti, tarkime, platformose suspaudžius terms of service mygtukus, tačiau, kaip parodo knygos autore, šis įsivaizdavimas dažnai apgaulingas. Iš instrumentalizmo ir kontrolès imperatyvo kylanti totalinio aplinkos reguliavimo tikslą i̇manoma pasiekti tik tada, kai tyrimo objektas yra totalaus nežinojimo režime. Automatinius procesus viešojoje erdveje kartais pateisina ir kone diktatoriška retorika apie tai, jog „neturime kitos alternatyvos“.

Žmonès siekia komforto, todèl jie noriai naudoja ir vis patogesnes sumanias buities ir darbo priemones. Individai paprastai neturi laiko ir jègų detaliau aiškintis, kas surašyta kontraktų ar vartojimo sąlygų puslapių gausybẻje. Savo ruožtu, net ir pasiryžimas iššifruoti sekimo kapitalizmo aprèpties mastą, sekant knygos autorès žodžiais, yra pasmerktas nesėkmei dẻl istoriškai beprecedentès mokymosi perskyros (division of learning). Ši perskyra savo ruožtu igalina žinojimo bei kompetencijų perskyrą (division of knowlede), arba kone totalią asimetriją tarp bendrovių įrankius konstruojančių ir juos valdančių „žiniuonių“ ir paslaugomis besinaudojančių eilinių žmonių. Kadangi žinios, valdžia ir galia vis labiau priklauso sekimo kapitalui, kuriam viso labo esame „žmogiškieji gamtiniai ištekliai“" ${ }^{\text {“ }}$, nebetenkame galimybès naudotis ir savo pačių patirtimi ar kontroliuoti naujụjų žinių pobūdị.

Kalbant apie išteklius, tikslinga atidžiau pažvelgti būtent ị taikomųjų mokslų uždavinius bei objektyvumo sampratą, visų pirma kompiuterių ir duomenų mokslų lauke. Kaip sakyta, nauji matematiniai metodai ir dirbtinio intelekto įrankiai šiandien neapsiriboja elgesio stebejimu, fiksavimu, analize ir prognozavimu. Jie pade-

8 Kaip čia neprisiminus ir šiandienos darbo rinkas užvaldžiusio švelnaus spaudimo darbuotojams nuolat prisitaikyti prie vis naujesnių „globalaus pasaulio iššūkių“ bei vadintis bendriniu žmogiškụjų išteklių (arba žmogiškujjų resursų) vardu. 
da aktyviai formuoti žmogaus elgesị būtent toje stadijoje, kai individas apie savo veiksmus dar net negalvoja. Taigi ir naujojo kapitalizmo gamybos būdai apjungiami su sudètingoms naujomis elgsenos modifikavimo priemonėmis, kurias igalina mašininio mokymo procesai, metodai ir taktikos. Kalbėdama apie pastarąsias, Zuboff pasitelkia ankstyvụjų socialinės psichologijos ir kitų instrumentalizmą aukštinusių mokslų prielaidas, naudotas stebint ir taip pat (per)formuojant laukinių gyvūnų elgesi - bandų ir būrių judejjimo ịpročius ir pan. Iš gamtos, statistikos, taip pat ir vèlesnių kompiuterių mokslų eksperimentų kyla ir autorès naudojami nesąmoningą skaitmeninių spiečių, genčių ar grupių modifikaciją iliustruojantys gana specifiški, sakyčiau netgi vulgaroki, tačiau svarbūs terminai - populiacijų derinimas, suvarymas ir elgesio suformavimas (angl. tuning, herding, conditioning).

Pasak Zuboff, populiacijų sekimas, stebèjimas ir priežiūra (galima prisiminti, jog angl. surveillance vienaip ar kitaip apima visus šiuos aspektus) veikia kaip savotiškas radikaliojo bihevioristo B. F. Skinerio psichologinių tyrimų tęsinys, kai žmonès, panašiai kaip ir kažkada gyvūnai, buvo pradèti redukuoti ị elgesio modelius ir refleksus. Šis vienas garsiausių XX a. vidurio psichologų nebuvo linkęs teikti pernelyg daug reikšmės tokiems ,iracionaliems“ dalykams, kaip individuali žmogaus valia; jo tyrimai kur kas labiau orientavosi $\mathfrak{x}$ socialinès sanglaudos auginimą ir darbuotojų efektyvumo stiprinimą. Savo ruožtu radikalų instrumentalizmą šiandien kritikuojanti Zuboff analizuoja biometrinių ir kitų duomenų rinkimu besiremiantį verslą, kuriame nepriverstinai, tačiau visomis įmanomomis priemonemis, siekiama slopinti ir galiausiai naikinti žmogaus apsisprendimo autonomiją. Matematiniai ir statistiniai metodai dabar pasitelkiami efektyvesniam ir greitesniam su elgesio modeliavimu susijusiam rezultatui pasiekti, o ne tam, kad būtų atsižvelgiama ị pavienius kieno nors įnorius.

Duomenų mokslas mus traktuoja kaip spiečius, kolonijas ar būrius, todèl tiksliụjų ir socialinių mokslų, kuriais grindžiamas sekimo kapitalizmas, giminystę būtent su biheviorizmu siejanti Zuboff daug dèmesio skiria tokių reikšmingų kompiuterių mokslininkų kaip Alexas Pentlandas idejų ir viešosios retorikos kritikai. Pentlando teigimu, socialinès medijos tampa esmine technologija igyvendinant suvarymo imperatyvą, nes socialinis spaudimas čia gali būti itin efektyviai kontroliuojamas ir apskaičiuojamas. „Socialinès fizikos“ prieigos, pasak matematiko, leidžia pasiekti maksimalią kooperaciją socialinių tinklų erdveje per tam tikrą tiksliai apskaičiuojamą paskatų sistemą. Pastaroji suteikia galimybę keisti tarpusavio ryšius tarp individų ar jų grupių norimomis kryptimis né nelaukiant, kol, pvz., socialinio tinklo paskyrų savininkų elgesys pasikeis individualiame lygmenyje. Asmens suverenumas traktuojamas kaip tai, kas vis dar leidžia rastis neprognozuojamam aktyvumui - pastarasis sekimo kapitalizmo sistemoje yra nepageidaujamas.

Maksimaliai instrumentalizuotoje visuomeneje, pasak Zuboff, nelieka vietos ir politikai, nes pastaroji remiasi vertybėmis, susitarimais, argumentacijomis, konf- 
rontacijomis ir visu tuo, kas tampa bereikalingais trukdžiais žengiant ị sekimo ateitį. Panašiai kaip kad biheviorizmo teoretikai Maxas Planckas, Maxas Meyeris ir B. F. Skinneris numate, instrumentiškai konstruojamoje visuomeninejje pravartu minimalizuoti politinę mūsų gyvenimo pusę. Tai padeda išvengti nemalonių netikètumų, atsitiktinumo ir klaidų. Šiuo atveju Zuboff įžvalgiai pastebi, jog sekimo kapitalizmas netgi apverčia ịprastą teorijos praktinio pritaikymo eigą. Kuriant naujus skaitmeninius ịrankius technologijų eksperimentai ir proveržiai vyksta kur kas sparčiau, nei immanoma suformuluoti naują visuomenès raidą grindžiančią bent kiek padoresnę teoriją. Deja, kol kas matematiniais modeliais besiremiantis ir Big Tech monopolijas personifikuojantis anonimiškas Didysis Kitas, Zuboff teigimu, siekia plèstis iki totalaus racionalumo, pakeliui naikindamas bet kokius pasipriešinimo, idiosinkrazijų ir kvailam užsispyrimui prilyginamų žmogiškųjų frikcijų šaltinius. Tačiau svarbūs „trukdžiai“ yra vienintelès žmogui dar likusios privatumo bei sakralumo erdvės.

Žinoma, prabilus apie totalitarizmą, išsyk kyla pamatinis laisvos valios klausimas. Neretai teigiama, jog žmonès iš esmès yra laisvi ir, pvz., nepirks produkto vien dèl to, kad prieš juos ekrane staiga iššoko reklama. Vis dèlto sekimo kapitalizmo operacijos, kaip sakyta, neturi nieko bendro su laisva pirkejjo valia ir sąmoningu apsisprendimu. Tarp daugelio pavyzdžių tą ypač gerai atskleidžia Google veiklos plètros ir kompetencijų sritys, toli gražu neapsiribojančios internetinès paieškos sistema ir rekomendacinių algoritmų kūrimu. Šios kompanijos gebėjimas sukurti pasaulio žemėlapi, kone realiu laiku fiksuojantị realias oficialių transakcijų, visų pirma komercinių, vietas, ar geolokacijos priemonėmis iš anksto numatyti žmogaus judejjimo trajektoriją, byloja kai ką daugiau. Tokį „daugiau“ liudija kad ir kompanijos veržimasis ị dirbtinio intelekto valdomų (žmogaus nepilotuojamų) transporto priemonių sritị. Skaitant knygą aiškèja, jog Google siekis, kartu su kai kuriomis kitomis techkompanijomis, nerti ị gana specifišką ir vis dar komerciniu požiūriu gana egzotišką rinką vyksta ne dẻl to, jog šiam IT gigantui rūpètų kuo greičiau išspręsti individų judumo ar ekologiškų automobilių patikimumo problemas. Beje, $\mathfrak{i}$ ateitị orientuotų transporto technologijų sritị jau šiandien ženklina kai kurie itin baugūs Zuboff minimi su draudimo kompanijomis susiję precedentai, iliustruojantys, kaip sekimo kapitalizmas palaipsniui paverčia mus visuomene be sutarties, nepaisant daugybės puslapių smulkiu šriftu surašytų paslaugų teikimo sąlygų.

\section{Visuomenè be sutarties, bet su kapitalizmu?}

Nors nuo neatmenamų priešistorinių laikų sutarties sudarymas išreikšdavo žmonių tarpusavio pasitikejjimo ir solidarumo siekį, dabartinèmis sekimo kapitalizmo sąlygomis teisinio kontrakto įmanoma palaipsniui atsisakyti būtent todèl, jog naujieji sekimo įrankiai automatinèse sistemose geba produkuoti užtikrintumą. Garan- 
tuotas rezultatas vis dažniau gali būti pasiekiamas be pasiryžimo, pažado, dialogo, bendrai suvokiamos prasmès, susitarimo, ginčo, sąmoningo problemų sprendimo ir pasitikejjimo. Kai su mašininio mokymosi ir naujų DI algoritmų pagalba draudimo kompanijos gali puikiai numatyti ne tik mūsų būsimas pajamas, bet ir baimes, sveikatos sutrikimus ar polinkị (ne)rizikuoti, nebelieka ir abipusị pasitikejjimą ir sąmoningą ịsipareigojimą vienas kitam apibrěžiančio santykio. Kitaip tariant, kai elgesys tampa beveik totaliai permatomas ir nuspëjamas, pasižadèjimo (kurị galima vykdyti arba ne) idèja „pakimba ore“. Todèl naujojo duomenų kapitalizmo sąlygomis gana vienpusiškai steigiamas ir radikaliai naujas teisinis režimas.

"Ǐsontraktinimas“ (angl. the uncontract) šiame naujame režime sugestijuoja savotišką naujo santykio erdvę, kurios pobūdị knygoje iliustruoja Zuboff cituojamų apie „,visiems patogią" ateitị samprotaujančių kai kurių korporacinių teisininkų pasisakymai. Kalbama apie tai, jog, tarkime, Google visa laiką gali žinoti ir kur mes esame (dèl navigacijos algoritmo), ir ką mes galvojame (dèl paieškos sistemos). Dèl nesąmoningai mūsų naršyklèje ir kitur paliekamų tūkstančių pèdsakų taip pat yra nuspẻjama daugybè kitos informacijos apie mūsų prioritetus ar veiksmus. Apie mus kažką svarbaus pasako gramatinès spausdinimo klaidos, kurias rašydami čia pat ištaisome, pasirenkamos naršyklių programų ikonèlių spalvos, būsimus sveikatos sutrikimus išduodanti rankos judesio maniera, kuria valdome kompiuterio pelę, greitis, kuriuo spausdiname (žinoma, ne mažiau svarbūs yra maniera bei greitis, kuriuo vairuojame automobilį) ir t. t. Kažkur anapus mūsų sąmoningo pavidalo glūdintys idealūs „skaitmeninių signalų portretai“", be abejo, rūpi viešojo sektoriaus institucijoms, tačiau dar labiau - stambiosioms privačioms finansų îmonèms, visų pirma - bankams ir draudimo kompanijoms.

Iš anksto garantuotoje ateityje, kurioje vis labiau užtikrintai diversifikuojamos mums teikiamos (arba kaip tik staiga nebeteikiamos) paslaugos ar jų paketai, tampame savo elgesio tremtiniais. Klausimas, ar ši globaliose finansinèse transakcijose tarpstanti sistema, kurioje atsižvelgiama ̨̣ profiliavimo procese surenkamus duomenis ir kuri remiasi tobulomis rinkos predikcijomis, vis dar yra kapitalistinè, tampa itin savalaikis. Juk kai dabarties, ir netgi ateities, rinkų rezultatai yra praktiškai žinomi, nebelieka ir rizikos. Monopolinę galią iggavę Big Tech sekimo kapitalistai kontroliuoja ir laisvę, ir žinojimą, tačiau jie nebèra tradicinès laisvosios rinkos dalyviai. Liberaliojo kapitalizmo teorijos kalba apie verslą, kuris negali iš anksto atspèti savo pelno dydžio (nes tik nematoma „laisvos rinkos ranka“ natūraliai viską „,sustato ị vietas"). Beje, sekimo kapitalizme ši ranka yra puikiai matoma, bet tik vienai pusei. Pasak Zuboff pasitelktos taiklios alegorijos, naujoji pirštinè šią gyvają nematomą ranką spaudžia vis labiau, kol beveik nebelieka vietos spontaniškam suspurdejjimui. 
Kai itin nedidelè monopolinè rinkos dalyvių dalis žino (beveik) viską, o likusieji nežino (beveik) nieko, išgaruoja ir laisvo judesio galimybès.

Žinoma, mes vis dar galime teigti, jog sekimo kapitalizmo pirštinė žmogaus patirtis apgaubia stipriai, bet švelniai, nejuntamai ir be prievartos. Vis dèlto čia pat verta prisiminti ir tai, jog radikalios indiferencijos režimu veikiančios monopolinès kompanijos su savo niekaip neiššifruojamoje paslaptyje glūdinčiais algoritmais neturi jokio betarpiško santykio nei su asmeniu, nei su konkrečios vietos ar šalies bendruomene. Net ir tuomet, kai žinios, gautos iš mūsų elgesio, grąžinamos mums taip vadinamojo „pirminio teksto“ pavidalu - kaip geresnè asmeniškai mums pritaikyta paslauga ir tuo pačiu kaip savotiškas atlygis už dalyvavimą - paralelinès operacijos nuolat akumuliuoja milžiniškus kiekius „šešèlinio teksto“ pertekliaus. Būtent šis perteklius igalina kurti predikcijos produktus, kurie skirti visiškai kitoms rinkoms ir apie kurių egzistavimą socialinėje medijose nauju ịrašu besidalinantis žmogus nè neįtaria.

Kalbant kiek buitiškiau, predikcijos realiu laiku vykstančiuose aukcionuose parduodamos verslo klientams, o konkretaus verslo rūšis gauna galimybę tam tikru, labiausiai tinkamu, momentu pasiūlyti žmonèms prekių reklamą (paprastai dar ir su nuolaidos kuponais kaip tik šiandienai). Vis delto perkami produktai visų pirma yra jaukas, kuriuo individai priviliojami ị tam tikras operacijas, o mūsų asmeninė patirtis išsyk siurbiama ir supakuojama kaip priemonė, tarnaujanti Didžiajam Kitam. Sekimo kapitalistai siekia nuspèti susipažinimo su reklama ir spustelejjimo arba kliktelejjimo santyki (angl. click through rate) - šiuo atveju ne tik galutinis spustelejjimas ant mygtuko „pirkti“, bet ir klikų intensyvumo duomenys turi komercinę vertę, panašiai kaip ir bet kokia „šešèlinio teksto“ pavidalus igaunanti informacija. Dèl tokios informacijos ateities elgesio rinkos jau gerokai pranoko tikslinès reklamos ar mažmeninès prekybos sferas ir persmelkè finansų, draudimo, nuomos ir kitas sritis ${ }^{9}$.

Nors Zuboff, kaip minèta, teigia, jog didžiųjų duomenų kapitalizmas naikina politikos galimybę, nesunku būtų teigti ir priešingai. Viena vertus, privatizuota instrumentinè socialine tvarka iš tiesų yra radikaliai indiferentiška politiškumui ir subjekto jautrumui. Kita vertus, internetinèmis transakcijomis grịsti duomenų verslai de facto tapo politika. Mat nepaisant to, jog didžioji dalis knygoje minimų technologinių procesų yra anapus mūsų suvokimo, o monopolijose koncentruojasi

9 Žinia, čia neturètume pasiduoti pagundai sekimo kapitalizmo ịsivaizduoti kaip kokio nors neva nuolat sprendimus už žmogų priimančio visa apimančio gudraus dirbtinio intelekto. Svarbu akcentuoti būtent tai, jog automatizuotos informacijos srautai siejasi su neaiškiais, t. y. žmogui nepažiniais, profiliavimo informacijos rezultatais, kurie dažnai pasireiškia ir kaip savotiškos privatumo „kliurkos“. Vienas iš kurioziškų pavyzdžių JAV - apie paauglès nèštumą iš prekybos centro gaunamos reklaminès ir kt. „personalizuotos" informacijos sužino jos tèvai, nors pati mergina apie šị svarbų faktą dar net nenutuokia. 
tiek žinojimas, tiek ir laisve, šiandien visuomenè vis dažniau išgirsta, jog, tarkime, socialinių tinklų kompanijos kone globaliu mastu jau geba kontroliuoti žodžio laisvę, nustato cenzūros standartus ar asmeninès saviraiškos ribas. Viešojoje politikoje vis dažniau girdime skambant tokius specifinius terminus kaip algoritmų diskriminacija (darbo rinkoje), skaitmeniné atskirtis, sekimas, kibernetinis saugumas arba hibridiniai išpuoliai prieš demokratines struktūras. Trumpai tariant, internetas ir politika senokai nebèra du atskiri dalykai.

Kinijos pavyzdžiai knygoje minimi tik probègšmais, pvz., aptariama vadinamoji socialinio kredito sistema. Zuboff mieliau pademonstruoja, jog panaši sistema, t. y. nuolatinis žmonių „bandos suvarymas“ $\mathfrak{i}$ sekimo režimą, egzistuoja JAV. Tai natūralu - knygoje pateikta sekimo kapitalizmo analizè remiasi daugiausiai JAV milžinų, tokių kaip, Microsoft, Amazon, Facebook, IBM ar Apple, istorija. Šiandien taip pat žinome, jog kai kurios iš pažiūros progresyvios vakarietiškos IT kompanijos tyliai, pernelyg nesiafišuodamos, bendradarbiauja su autoritarinèmis komunistinès šalies valdžios struktūromis. Vis dèlto kaip bežiūrèsime, automatizuotai valdomos instrumentinès visuomenės konstravimas vardan užtikrintų politinių ir socialinių dividendų didžiausios Azijos šalies atveju yra realesnis nei bet kur kitur. Skaitmeninè Kinijos galia jau dabar yra tapusi pagal Vakarų socialinių mokslų pavyzdžius Zuboff aprašyta „bihevioristine dievybe“, lemiančia tiek piliečių kūnų, tiek ir jų minčių judejjimo kryptis.

Knygoje nekalbama apie tai, jog skirtingų pasaulio šalių ar regionų pasirinktos ateities vizijos ir darbotvarkẻs vis labiau išsišakoja. Manau, reikia pastebèti, jog kuriant skaitmeninę ateiti, Kinijos, Rusijos, JAV ir ES scenarijai ima skirtis. Ilgametis Zuboff tyrimas darytas anksčiau, nei didžiosios šalys pradejo rašyti ir skelbti savo dirbtinio intelekto strategijas bei kryptis (maždaug nuo 2017 m.), tačiau šiandien jau galima minèti, jog ES, ko gero, turi patikimiausią teisinę sistemą, kurios padedama mėgina atsispirti Big Tech galiai. 2018 m. pavasarị ỉsigaliojęs europietiškasis Bendrasis duomenų apsaugos reglamentas daug kam pasirodè kaip pirmas rimtas vilčiu teikiantis žingsnis. O tokie pavyzdžiai, kaip Google neseniai paskirta milijardinė JAV dolerių bauda dèl rinkos monopolizavimo, savo ruožtu, iliustruoja ir ryškesnes pergales. Apie antimonopolinius ịstatymus pastaraisiais metais intensyviai diskutuojama JAV (linksniuojant europietiškąj BDAR, neretai minimas ir naujasis Kalifornijos valstijos vartotojų privatumo įstatymas). Politinį sąmoningumą ir aktyvizmą pačiose JAV iliustruoja didžiųjų kompanijų darbuotojų išviešinti kai kurie skandalingi faktai. Taigi nesitaikstymas su duomenų kapitalizmo grimasomis ir tamsiomis veiklos pusėmis leidžia manyti, jog sąmoningejja tiek skirtingų šalių visuomenès (bendrosios žinios apie platformų verslą nuo Cambridge Analytica skandalo laikų gerokai išaugo), tiek ir technologijų inžinieriai. 
Kaip bevertinsime naujų i̇statymų galimybes, Zuboff ir kitų panašiai mąstančių socialinių kritikų išjudinamas bei pastaraisiais metais visuomeneje besikristalizuojantis suvokimas, jog intymiausios ir asmeniškiausios mūsų patirtys yra „nulaužiamos" Silicio slènio ir naudojamos kaip žaliava ypač pelningiems skaitmeniniams produktams, iš tiesų sukrečia. Visų pirma tuo, jog ganètinai ilgą laiką žmonės nuoširdžiai džiaugèsi „už dyką“ internete gaunamomis paslaugomis, nesusimąstydami apie tai, kokiais būdais iki kosminių aukštumų išaugo kai kurių IT kompanijų piniginè vertè. Vartotojai nemate, jog realusis pasaulis praktiškai susiliejo su Didžiojo Kito nematomais šešèliniais tekstais, vardan kažkieno kito pelno. Zuboff ši aklumą aiškina visų pirma tuo, jog naujoji sistema yra beprecedentè. Tai reiškia, jog ji negali būti atpažinta pagal ankstesnes istorines analogijas. Paskubomis vykstantis plěšimas kone vidury baltos dienos neatpažistamas kaipo toks, o bet koks méginimas ¡̇sigilinti $\mathfrak{i}$ tai, kokiu nę̨tikètinu mastu mes nuolatos esame sekami, dalinami, ekstrapoliuojami ir modifikuojami, sukelia kone fizinę apatiją.

Tapę iš duomenu sudarytomis substancijomis, mėginame kaip nors pa(si) teisinti ir racionalizuoti savo situaciją, susikuriame psichologinius gynybos instrumentus („aš neturiu ko slèpti“), arba kaip tik slepiame galvas (skaitmeniniame) smèlyje ir taip pasirenkame iš frustracijos kylantị nežinojimą ir bejejiškumą. Šiuo atveju Zuboff pasiūlo ir tam tikras intervencijas, tarkime, skatina žmogų reikalauti teisès ị šventyklą (knygoje tai - intymios sakralinès erdvės metafora, paprastai suvokiama kaip galutinè persekiojamo žmogaus sléptuvè). Autore šaukiasi ir „teisès $\mathfrak{i}$ ateities laiką" (tai vis dar galiojanti žmonių teisè ateityje netapti tiesiog skaitmeniniais informacijos nešikliais). XX a. pradžios anti-monopolinių įstatymų kūrimo istorija JAV, arba XX a. vidurio kone katastrofiškos ekologinès nesèkmès, sukrètusios visuomenę ir paskatinusios visus atsitokèti, mokslininkei tampa istorinių precedentų pavyzdžiais, kai bendruomenès ima „atsibusti“, o ̣̇statymų kūrèjai - mobilizuotis.

Baigdama dar sykị akcentuosiu, jog piešdama plika akimi nematomo ir nejuntamo duomenų totalitarizmo erdves ir ribas, už kurių išnyksta bet koks žmogaus orumas, Zuboff nesiūlo atsisakyti interneto, skaitmenizacijos ar (skaitmeninio) kapitalizmo teikiamų galimybių. Sekimo kapitalizmo nę̇manoma ịsivaizduoti anapus skaitmeninès aplinkos, tačiau pats savaime šis iškreiptas ir resursus be skrupulu plèšiantis kapitalizmas neturètų būti tapatinamas su gyvenimu skaitmeniniame pasaulyje. Kaip jau minèta, tai ne technologija, bet greičiau principas, kuris persmelkia ir pajungia technologiją savo tikslams. Instrumentalizmą demaskuojanti knyga šiuo atveju gali būti traktuojama kaip ryškus ir reikšmingas palinkejjimas visuomenei kuo greičiau atsikratyti žmogiškosios ịvairovès sąskaita parazituojančios sekimo logikos ir, susigrąžinus mums reikšmingą pasauli iš matematinio racionalumo distopijos, plètoti kitokias ekonomikos paradigmas. 